Journal of Law \& Social Studies (JLSS)

Volume 3, Issue 1, pp 38-43

www.advancelrf.org

\title{
Honor Killing: A case study of Pakistan
}

\author{
Shagufta Kanwal \\ LLM-International Trade Law \\ Judicial Clerk (Supreme Court of Pakistan) \\ Email: shaguftakanwal227@gmail.com
}

\begin{abstract}
Pakistan along with many other parts of the world has the persistent phenomenon regarding Honor Killing. This research article states the case study of Pakistan in relation to honor killing, its causes and the struggles made by national and international community to reduce such like honor crimes. The effects of several amendments that are previously made have been discussed in the piece of paper stating therein that all the amendments are unable to tackle the deficiencies. There is an actual desire of further improvements and latest amendments that is required to be resolved to eliminate the issues in hand. In the last section of the paper, it is addressed that how Pakistan has made up with the international obligation and its compliance towards the protection of women rights. Analyses of the elements that are keeping the practice of honor killing as well as the recommendation to amend the relevant laws are explained in this research article.
\end{abstract}

Key Words: Honor Killing, CEDAW, amendments, Pakistan, women's right

\section{What is Honor Killing?}

To trigger this act only the suspicion that women committed an offence is more than enough. Mostly, the women are killed by their father, brother and even by her husband. While in this offence, other women in the family are equal perpetrator. Generally, the offenders are praised to restore the prestige of family and mostly they are sentenced to lessen punishment for extenuating circumstances. To commit the crime, an underage man is chosen so that he could avail the judicial leniency. In some societies, the implementation of honor crimes be rite de passage to show and guarantee the social maturity. Honor killing have been taken place on a big scale in so many leading and developed countries as well as in the following ones: UK, Turkey, Germany, Pakistan, India, Iran, Kingdom of Saudi Arabia, Afghanistan, Jordan, Yemen and so many others.

In majority Muslim societies, honor killing is wrongly bonded with religion and continuation of this crime is treated as religious concession. No instances ratifying the practice of honor killing can be found in Quran or in Hadith as Islam is the religion that protects the women's right. On the other side there are some Muslim countries where the term honor crime does not exit like Indonesia and Malaysia. The kinship is main social, political and economic unit in traditional patriarchal society along with inheritance issue. Reproductive ability of the women is the sole ground of kinship structure and its continuity. Emphasize is laid on that no compromise of women's sexual and reproductive powers would be bearable because that is the only standard to ensure the legitimacy of children. In these societies, the status of the family is mostly subordinate to individual's right and status. Most often the woman is regarded as minor throughout her life and barred from the shares of her father's and husband's property.

Particularly, the homicide of women is rooted from the ancient (desert) tribes to uphold the honor of the male society and the women were considered as treasure box for her family honor or pride. "Ghairat" was considered as one of the main elements of family's stature in the tribal community. Women were considered as commodity that can be purchased from her father, brother or male relatives in consideration of dowry. So, it would be true to say that women were acknowledged as an investment for a man done by him for his honor that was much important to keep his standing 
and race intact in the society. If the women expressly deviate from this setup, she was punished by him and most often killed by him to hide the shame and avoid being called 'socially impotent' or Beghairat.

\section{Reasons behind Honor Killing in Pakistan}

For varying reasons, the women of different age groups in Pakistan fall the victim of Honor Killing. Poverty, tribal laws, lack of education, culture, religious mindset, jirga system, divorce and marriage against the will of family, customs, settling of debts, previous enmity and provoking by community are the main reasons behind the honor crime. No exhaustive list can be enumerated to illustrate the causes of honor crime. Today in Pakistan the honor crimes are in uncontrollably increasing and unfortunately socially accepted. Honor crimes victims are between the newborn to old age women irrespective of married, unmarried or resident of rural or urban society. Impunity of perpetrator is one of the important motivations causing rapid increase in honor crime, which is enjoyed by the offender. Reporting the honor crime is very rare in Pakistan, if it is done so then instead of exemplary punishment, the lighter punishments are given to the perpetrator in the male dominant society that really affects the judicial system of Pakistan.

It is not possible to state the definite causes and activities which are causing the main potential of honor crimes. However, any legitimate or illegitimate act at the wrong place may trigger the flair of so-called maintaining honor. Motivations behind the honor crimes are often property, inheritance, monetary gains and an attempt to lessen the number of successors in the prospectus of ancestral property. The fiscal compensation is received when a woman is killed being declared Kari with any rich man, to forgive that rich man as Karo. It is well known tradition that, no matter if the charge is credible or not credible, Karo must pay the compensation to save his life.

\section{Reported Cases in Pakistan}

On $25^{\text {th }}$ September 2017, two daughters were killed by their father with the allegation of illicit relationship with boys, being ashamed off the illicit relationship; they were killed in the name of honor by their father. Domestic violence is rampant in patriarchal culture-based countries as Pakistan, where men are authorized to kill the female relative as the punishment of an act not acceptable for male dominant society. Jirga and tribal council are the main male dominant bodies. The strictest punishments on the acquisition of honor came from these bodies in the major reported cases of honor killing in our country. Most of the honor crimes go unreported, suicide or portrayed as natural death due to which no official credible figure of killing can be found. As reference, the honor killing by the male family member in KP is rapidly increasing with the passage of time.

In August 2017, Karachi, Bakht Jan age 15 and Ghani Rehman age 17 has been killed on the verdict of jirga by giving electric shocks on the allegation that both violated the "Honor Code". Resident of Lahore murdered his wife as she refused to quit a job at factory where she was working as labor person. Naghma of age 13 resident of KP was killed on the pretext of honor killing as jirga council pronounced the verdict being running away from house with an unknown man. She was luckily being saved by the security forces. In 2016, Qandeel Baloch, Pakistani model was killed by her brother. After the model's murder, public protest rooted the footprints and encouraged the parliament to pass the law naming as "Anti-Honor Killing Law" to discourage such practices. The new and severe punishments are introduced in this law and to some extend the loopholes has been filled by the parliament through the legislation as previously the legal heirs were authorized to grant pardon to the offender. Recently the unreported case of honor killing is seen naming the fame "Shamsa" who was stoned to death directed by her uncle and family in the name of honor. The alleged offence was only her dance performance at her cousin wedding ceremony, the dance is the normal occurrence and traditional part of every wedding ceremony in Pakistan, but her uncle took it as immoral and unethical act.

Another case reported o $7^{\text {th }}$ April 2018 when a young man killed her 8 months pregnant sister just because she contracted marriage against the will of her parents and with the man of her own choice. The verdict to kill the women on the name of honor was come from village jirga council and her father was declared as Kari who instigated her son to kill the daughter in order to maintain the honor and self-esteem in society. The only alleged offence was the marriage contract in the court of Sukkher in 2016 with the man of her choice who belongs to different caste; she was murdered by her brother while having a child. On the same day, another woman was killed having the four children on the same grounds by her male family members.

Some of the leading reported and unreported cases of honor crimes have been discussed in this section. Still there are some fundamental loopholes in the criminal law, existing laws are inefficient and proving deficient for the victim's relief in the prevailing situation where honor crimes, despite the illegal in nature, are increasing day by day and 
uncontrollable situation is taking place in the society. Although the gap in criminal law is summarized by human rights activists and civil society time to time.

\section{Continual phenomenon of Honor Killing}

There are two major legal forums in Pakistan that are dealing with the honor crimes: Informal Legal system and Formal Legal system. Informal legal system is based on jirga, village council or tribal council. Informal legal system's verdicts purely rely on rules of the tribes, norms and culture particularly known as "Honor Code" of the group of society. This honor code is administered by Quasi-Judicial nature tribunal that is typically based against the women of the society. Informal legal system was declared as illegal in 2006 by Supreme Court of Pakistan but afterwards in 2017 after a prolong debate it is declared as legal form of adjudication. ADR Bill, 2016 passed in 2017 and Alternate Dispute Resolution system is authorized to deal with 23 types of Criminal and Civil disputes. In Pakistan, formal legal system is the body of rules which is consisting of customary law, English and Islamic Law. The hierarchy of courts in our country is governed by the Constitution of Islamic Republic of Pakistan and the courts are working according to their jurisdiction. Problem exists in both formal and informal legal system of justice regarding honor crime that is why it is necessary to mention the both systems.

Judicial efforts are made to stop the honor crimes in Pakistan but still the problem is persistent in Pakistan. No specific statue was given by the state to deal with honor crimes till 2004. As the result of which there is a huge collection of discriminatory judgments and narrow interpretations in pre-2004 jurisprudence. Amendments were made in 2004 regarding honor crimes in criminal law and criminal proceedings. To mention the pre-2004 situation is important as well, there was an exception named 'Grave and Provocation Plea' where a husband could get benefit if he kills her wife if she is found guilty of adultery- a pre-partition norm. A hot debate started after the partition about Islamization of laws, special intention was given to criminal law reforms and more specifically murder, injuries and honor killing. To eliminate the anti-Islamic elements, large numbers of changes were made in the existing laws through Qisaas and Diyat Ordinance.

Homicide and manslaughter were divided into four categories and it was decided to punish the offender by keeping in view the relationship between the offender and the deceased person instead of severity of crimes and facts of the case. Qisas, Diyat and Tazir were declared as alternative forms of punishments. Specific and strict rules are required to be followed to enforce the Qisas punishment as willful confession of the offender or competent witness. In case the requirements are not fulfilled then Qisas will not be awarded to the offender and alternatively he will be punished with Tazir as punishment under normal law. Qatl-e-khata and few close relatives were exempted for the Qisas punishment and only Tazir was available option for them. It was concluded that reattributed punishment of Qisas would only be applied according to the injunctions of Islam. Formal permission granted to the legal heirs of the injured or deceased by the law to forgive the offender or to enter into compromise. Indirectly the changes in the laws authorized the Honor crimes. The term Masoom ud Dam was introduced to give lesser punishment to the offender and self-defense was also a good exception to honor killing.

\section{The Criminal Law (Amendment) Act 2004}

Continuous efforts made by the civil society paid off after so many years, an act passed by the Government specifically to deal with honor crimes and declared the honor killing as illegal. In criminal law amendment act 2004, amendments made regarding honor killing punishment and expressed them as Honor Killing Law, various changes made in Criminal Procedure Code 1898 and Pakistan Penal Code 1860. The main addition to the existing law was the "qatl-eamd" carried out on the cause of honor killing. Despite of advocacy and legislature's full support, all the changes demanded by the civil society were not corporate in 2004 amendments. The major changes made in 2004 Act are illustrated here:

One of the major additions that have been made in 2004 amendments is the insertion of honor crime definition. The term honor crime is defined in the following words, "offence committed in the name or on the pretext of honor means an offence committed in the name or on the pretext of karo kari, siyah kari or similar other customs or practices." This definition of honor crimes impliedly allows the members of the family to kill the women or men just having the allegation that this family member brought dishonor to the family. Judicial powers also got limitations through after the 2004 amendments as no discretion was given to the courts to adjudicate on the matters where the Qisas would not been applicable according to the injunctions of Islam. 
Specifically, this discretely powers of court were withdrawn regarding honor crimes. State was directed to act as Wali or guardian in the case if necessary because according to the injunctions of Islam if the Wali or Guardian is offender then right of Qisas cannot be enforced so the practice of the offender being accepted as guardian was eliminated through the amendments done in 2004. Sentences were enhanced from 14 years to 25 years for honor crimes that brought the major changes. Badl-e-Sulah was declared as illegal in the 2004 amendments and specific penalty was fixed for this kind of honor crime because giving the women in consideration of something else is the infringement of fundamental women rights. In addition to this, if any of the wali is not agreed to waive/compound the right of Qisas or all of the wali are agreed to waive/compound, even then the principle of fasad-fil-ard would be attracted for the society's interest, in this situation the court is empowered to adjudicate the matter with imprisonment of 10 years.

\subsection{Deficiencies in the 2004 Amendment}

To discourage the crime of honor killing, appreciative efforts were made by the civil society through 2004 Act. But many deficiencies and loopholes could be seen in this act that had made the act inefficient on the face of it and lacked to provide the relief to the victims of honor crimes as demanded and struggled by the human rights activists and civil society. One of the major loopholes in this act was with respect to the punishment of honor crimes. Punishment was not mandatory for all the instances of honor crimes.

Proviso regarding waiving and compounding the Right of Qisas is still alive in the Act. No exceptions are made on the application of section 309/310/311 and 338E of Pakistan Penal Code to waive the right and to amend the category of crime relationship with the victim. Additionally, the discretionary powers are given to the court to punish the offender in the case of fasad-fil-ard with imprisonment of 10 years and maximum of 14 years as Tazir. The term fasadfil-ard also contains the expression of honor killing crimes but only for the cases where the legal heirs of the victim have been compounded or waived the right of Qisas. The offender can get the benefit with minimum penalty or no penalty at all through the discretionary powers given to a judge and consent of the parties to waive the right.

The definition of honor killing provided in the act is not exhaustive in nature because of the inclusion of "grave and sudden provocation" provision. Even after the 2004 amended act there is no compulsory punishment for the offender of honor killing crimes. Unlike penalties for the same crimes is still the main concern, for example in case of no compromise death or life imprisonment is awarded to the offender; no penalty at all or on the discretion of a judge 1014 years of imprisonment, acquittal or any amount of tazir. No liability is imposed on the family members of the offender being acting as the perpetrator of committing the honor crimes. Family members, jirgas, village council and punchiyat are equally responsible to encourage and validate the honor crimes so they are equally responsible and deserve the same punishment. Still judicial biasness is here to create the gender discrimination and award the wrong doers with minute penalty or no punishment at all. All these drawbacks of 2004 act have been clearly stated the aim of meritoriously prosecuting perpetrators of honor crimes.

\subsection{Efforts made to control Honor Killings}

Rapid increase in honor crimes cases led to continuous internal and external pressure. International community, civil society, NGOs and Human rights activist has taken step towards more concerned legislation to fill the gap in the previous laws and discourage the honor crimes. On 21 ${ }^{\text {st }}$ October 2016, "Anti Honor Killing Bill 2016" is passed in joint session of parliament and necessary changes are made in 2004 Act to curb the honor crimes practices. The focus of 2016 bill is the loopholes of 2004 criminal Law amendments. As discussed above, no provision was given to punishment the perpetrator of honor crimes. The judge was given a discretionary power in 2004 amendment to punish the offender in case of waiver or on compounding of the right of Qisas or where the principle of fasad-fil-ard is attracted. Some of the lacunas of 2004 Amendments were being focused and curd in 2016 Bill but still no comprehensive solution is provided by the Bill. The detailed discussion of 2016 bill is given below.

\section{The Criminal Law Amendment 2016}

Through the legislation of 2016 bill, the punishment period is extended to life imprisonment which is 25 years according to Pakistan criminal Law. Mandatory punishment of life imprisonment is fixed for the offenders of honor crimes by the provision of section 311 . According to 2004 amendment the discretionary power given to the judge in case of compounding or waiver or on the applicability of principle of fasad-fil-ard, the imprisonment of maximum 14 years was fixed. But in 2016 Bill, the life imprisonment which amounts to 25 years has been declared mandatory and fixed for the offender who commits honor crime. This provision is the true reflection of efforts made by the several institutions to curb the rapid increase in honor crimes. 
Still there are persistent loopholes in 2016 bill that is about imprisonment of 25 years recommended for honor killing crimes even if the offence is pardoned by the heirs of the victim, the criminal could be punished as the one who brought chaos or disorder in the society. Under the provision of 302 Pakistan Penal Code, death penalty or imprisonment for 14 years is recommended if the murder of simple nature is committed by the wrongdoer. Legislatures are still unable to draw the line of difference between the homicide on the name of "Ghairat" and homicide for any other reasons like previous enmity, property dispute or any other kind of offences which do not fall under the category of fasad-fil-ard. As discussed before, PPC's provisions works on the relationship between victim and offender, so meaning thereby, showing the close relationship between victim and offender, one can avail the benefit of lesser punishment. Hence if this proposition is applied the offender might be willing to avail the section 302 instead of 311 PPC, ultimately family members might pardon the offender to avoid the operation of section fasad-fil-arz. So basically, these concerns are nullifying the efforts of the state to stop the enhancing rate of honor crimes because in such like crimes, family members act as abettor or accomplice.

\subsection{Observance of international obligations}

The protection of individuals against the exploitation perpetrated by the government is one of the utmost concerns of the human rights law. Although the domestic violence against women committed by the private individual is not included in the sphere of International Human rights. The state's responsibility does not arise only when violation of treaty obligation takes place, but it must include the illegal act committed by the private individual. The lack of due diligence of state regarding domestic violence is another factor behind the rapid increase of honor crimes. Right to life is one of the most important fundamental rights provided in almost every human rights document including UDHR, 1948 while honor killing is the self-evident of violation of right to life.

Every document relating to Human Rights is free from gender biasness and stress is relied on the equality by providing that human condition is free from any kind of gender discrimination. The main concern is all about the protection of state and the individuals including therein the attitude of the state towards the individuals. So, it would not be meaningless to say that only the state is authorized to commit violation of rights. Convention on the Elimination of all forms of Discrimination against Women (CEDAW), 1979 is one of the biggest milestones to redress the gender biasness in human rights legislation; it usually called as International Bill of Rights for Women.

To protect the women rights is the main obligation of Pakistan being bound by the treaty. Pakistan is the member of United Nations so obliged by the Universal Declaration of Human Rights, 1948. Convention on the Elimination of all Forms of Discrimination against Women (CEDAW 1979) is also signed by the Pakistan which is one of the most international conventions to protect the women rights and gender discrimination. So, an International responsibility stands with Pakistan under CEDAW to protect the violence against women. To incorporate with the international treaties there is a dire need to include all these fundamental laws in the domestic or national laws. To fulfill the international obligations, three different laws are incorporated into national laws namely;

- Amendment in Criminal law, 2004

- Amendment in criminal law, 2006

- Anti-Honor Killing Bill, 2016

The first amendment the Wali is forbidden to take the benefit $\mathrm{f}$ close relationship and escape from the Islamic provision of Qisas and Diyat. While in the next amendment the distinction line is drawn between Zina and rape. In 2016 Bill, the mandatory punishment $\mathrm{f}$ life imprisonment is added irrespective of the situation that heirs have forgiven the offender.

\section{Conclusion}

Pakistan being an independent state can make norms, rules, laws, culture and tradition to protect the women rights. Rule of law is one of the main tools to punish the perpetrators as honor killing is an evil that is constantly taking the precious lives of women in the name of honor. There is no justification of honor killing in or religion so should not be spaced in our national laws as well. The unique redresses of so-called allegations against the women in the name of honor have no value at all. Pakistan is under the national as well as international obligation to investigate the root factors of these crimes and investigate to punish the wrongdoer. Right to life is guaranteed in the constitution of Islamic Republic of Pakistan and all other international laws in which Pakistan is a state party. A progressive curve could be seen in the contemporary legislative developments to control the honor crimes. Transformation of culture and tradition could be the effect tool to stop such likes curse. This transformation can be achieved by eliminating the 
factors $\mathrm{f}$ gender discrimination in Pakistan. All the recent struggles and legislation made by the Pakistan seems like baby steps towards the emerging situation of honor killing in Pakistan.

\section{References}

Cole, W. M. (2016). Convention on the Elimination of All Forms of Discrimination against Women (CEDAW). In the Wiley Blackwell Encyclopedia of Gender and Sexuality Studies (pp. 1-3)

Cook, R. (1994). State Responsibility for Violations of Women's Human Rights. Harvard Human Rights Journal,7,125,129.

Faqir, K., \& Atta, M. (2013). JIRGA: A Conflict Resolution Institution in Pukhtoon Society. Gomal University Journal of Research.

Weiss, A. M. (2003). Interpreting Islam and Women's Rights. International Sociology, 18(3), $581-601$.

Warraich, S. A. (2005). Honour: crimes, paradigms and violence against women. (L. Welchman \& S. Hossain, Eds.). Oxford University Press.

Vitoshka, D. Y. (2010). The Modern Face of Honor Killing: Factors, Legal Issues, and Policy Recommendations. Berkeley Undergraduate Journal, 22(2).

Goldstein, M. (n.d.). The biological roots of heat-of-passion crimes and honor killings. JSTOR. Retrieved from http://www.jstor.org/stable/4236668

Hawwa, A. F. (n.d.). The Historical Roots and Occurrence of Honour-Related Violence in NonMuslim and Muslim Societies. Books and Journals.Brillonline.Com.

Jennifer A. Zerk. (2006). Multinationals and Corporate Social Responsibility: Limitations and Jennifer A. Zerk - Google Books. Cambridge University Press.

Schacht, J. (1964). An introduction to Islamic law. Oxford University Press.

Ruane, R. A. (2000). Murder in the Name of Honor: Violence against Women in Jordan and Pakistan. Emory International Law Review, 14(3), 1523-1580.

Phyllis Chesler. (2009). Are Honor Killings Simply Domestic Violence? | Middle East Forum. Middle East Quarterly Spring, 16(march).

Khan, T. (2006). Beyond honour: a historical materialist explanation of honour related violence. 